\title{
Influence of Ripening Stage and Astringency Removal on Quality of Cold Stored 'Rama Forte' Persimmon
}

\author{
I. Sestari, F.K. Edagi, F.A.M. Terra, \\ D.G. Chiou and R.A. Kluge \\ Department of Biological Science \\ 'Luiz de Queiroz' Agricultural College \\ University of São Paulo \\ C.P. 9, 13418-900, Piracicaba, SP \\ Brazil
}

\author{
L.R. Antoniolli \\ Embrapa Uva e Vinho \\ Bento Gonçalves, RS \\ Brazil
}

Keywords: astringent persimmon, carbon dioxide, tannin, Diospyros kaki L., shelf life

\begin{abstract}
'Rama Forte' persimmon fruits were harvested at three ripening stages (yellow, orange and red) and exposed to $70 \mathrm{kPa} \mathrm{CO}$ atmosphere during 12 and $18 \mathrm{~h}$ at $22^{\circ} \mathrm{C}$ and $95 \% \mathrm{RH}$ to promote the polymerization of soluble tannins and remove the astringency. After the application of treatments, fruits were submitted to cold storage during 45 days at $1^{\circ} \mathrm{C}$ and $90 \% \mathrm{RH}$ (plus 7 days at $22^{\circ} \mathrm{C}$ ). After 15 days of cold storage (plus 2 days at $22^{\circ} \mathrm{C}$ ) fruits were completely non-astringent. After 45 days fruits were able to consume at the open chamber, regardless of the ripening stage and $\mathrm{CO}_{2}$ exposure time. Orange fruits exposed to $\mathrm{CO}_{2}$ during $12 \mathrm{~h}$ showed the higher weight loss at four and seven days at $22^{\circ} \mathrm{C}$, regardless of storage period. Exposure time to $\mathrm{CO}_{2}$ affected fruit firmness, and skin and pulp color. The exposure of fruit at yellow stage during 12 and $18 \mathrm{~h}$ to $\mathrm{CO}_{2}$ kept higher firmness up to four days of shelf life, in spite of storage period.
\end{abstract}

\section{INTRODUCTION}

'Rama Forte' persimmon fruit is the most important cultivar commercialized at Sao Paulo State (Brazil), mainly due to its excellent taste and nutritional value. The period of production and commercialization of 'Rama Forte' persimmon is short comprising only two to three months. This scenario, associated to high perecibility of fruit and regionalized market, results in lower price to producers and a loss of product during up to eight months of the year. The adoption of techniques such as cold storage may allow the postharvest period to be extended and consequently to obtain best prices and reduce postharvest losses. Another problem is related to astringency of fruit. The astringency is a common characteristic in immature persimmon fruit. Conversely, 'Rama Forte' persimmon keeps its astringency even when mature, in this way, there is a need to promote deastringency of fruit to make its consumption possible.

Several methods have been related for removing astringency in persimmon fruits, such as ethanol vapors, ethylene, high carbon dioxide or nitrogen partial pressures and warm water treatments (Antoniolli et al., 2002; Matsuo and Itoo, 1977; Ben-Arie and Guelfat-Reich, 1976).

Recently, it has been shown that $\mathrm{CO}_{2}$ treatment is significantly more efficient than application of ethanol in astringency removal (Yamada et al., 2002) though, the duration of treatment with $\mathrm{CO}_{2}$ depends on cultivar, temperature and ripening stage (Vidrih et al., 1994). Traditionally the deastringency process is made with ethanol by producers of Brazil, although it causes softening of pulp which makes the fruit manipulation and conservation difficult as compared to $\mathrm{CO}_{2}$ treatment. In previously trials carried out with 'Rama Forte' persimmon, it was observed that fruit at various ripening stages had different responses to deastringency treatments and subsequent shelf life (Vitti et al., 2007). Taking into consideration results of previous work, the present study aimed to evaluate the effect of exposure of fruits to high $\mathrm{CO}_{2}$ pressure during different times on removal of astringency of 'Rama Forte' persimmon and subsequent cold storage to extend the storage life and maintain the fruit quality. 


\section{MATERIALS AND METHODS}

Astringent persimmon fruits cv. 'Rama Forte' were harvested at ripening stage characterized as yellow, orange and red skin color at an orchard located at Itupeva, State of São Paulo, Brazil. Immediately the fruits were transported to the laboratory of Postharvest Physiology and Biochemistry of the 'Luiz de Queiroz' Agricultural College. After the selection and grading, samples were randomly divided and the treatments were applied. The removal of astringency was carried out through the exposure of fruits at each ripening stage to $70 \mathrm{kPa} \mathrm{CO}$ during 12 or $18 \mathrm{~h}$ at $22^{\circ} \mathrm{C}$ with $95 \% \mathrm{RH}$ in a closed chamber. The concentration of $\mathrm{CO}_{2}$ was monitored and controlled through gas analyzer. Following deastringency treatment persimmons were stored at $1{ }^{\circ} \mathrm{C}$ and $90 \% \mathrm{RH}$ for 15,30 and 45 days. The fruit samples were analyzed at harvest ( -2 days), at the end of $\mathrm{CO}_{2}$ treatment ( -1 day) and after each cold stored period (0 day), when the fruits were kept for seven days at $22^{\circ} \mathrm{C}$.

Flesh firmness was measured with TR-Fruit Pressure Tester, model 53205; measurements were performed on two opposite sides of each individual fruit after peel removal, with a $8 \mathrm{~mm}$ diameter tip. Fruit samples were weighed before and after each storage period to calculate weight loss (\%) during storage. Skin and flesh color of each fruit were determined objectively with a Minolta colorimeter (model CR 300), and expressed as parameters $L^{*} a^{*}$. The degree of soluble tannins was estimated visually by evaluating color development during the reaction between tannin with ferric chloride. Persimmon fruit were cut equatorially, and immediately the freshly cut surface was printed in a paper filter previously treated with a $5 \% \mathrm{FeCl}_{3}$ solution as proposed by Gazit and Levy (1963). The printed paper was scored visually on a scale from 5 (extremely astringent) to 1 (no astringent).

A completely randomized design was used with four replicates of three fruits. All data were evaluated through ANOVA, and subsequently, when statistical significance was found, were compared by m.s.d. test at $\mathrm{P} \leq 0.05$.

\section{RESULTS AND DISCUSSION}

After 15 days of cold storage no considerably influence of deastringency treatments or ripening stage on weight loss of fruit was observed (Fig. 1). During the exposure of fruit to ambient temperature a slight increase on weight loss occured in all treatments. Fruits harvested at orange and red skin color were not marketable after seven days at $22^{\circ} \mathrm{C}$. Thus, we performed the assessment of all quality parameters at this maximum period of exposure to ambient temperature.

On subsequent assessments, at 30 and 45 days at $1{ }^{\circ} \mathrm{C}$ plus seven days of shelf life, an increasing weight loss was observed in all fruits; nevertheless it was not visually perceptible (Fig. 1B, C).

During storage period at $1{ }^{\circ} \mathrm{C}$, 'Rama Forte' fruit had practically unchanged firmness values, regardless of ripening stage. Nevertheless, a loss of firmness was observed in all the treatments when fruit was removed from refrigeration to $22^{\circ} \mathrm{C} \mathrm{(Fig.} \mathrm{2).}$ After 15 days of storage, the exposure to $\mathrm{CO}_{2}$ during $12 \mathrm{~h}$ seems to delay, while $18 \mathrm{~h}$ shows to enhance, the softening of yellow stage fruit at four days at $22^{\circ} \mathrm{C}$. At this period, fruit at yellow stage treated with $\mathrm{CO}_{2}$ for the period of $12 \mathrm{~h}$ remained with satisfactory firmness for up to ten days of shelf life. Although the beneficial effects of high $\mathrm{CO}_{2}$ atmosphere on fruit quality are well known (Beaudry, 1999), it has also been shown that very high $\mathrm{CO}_{2}$ concentrations can cause undesirable physiological changes on fruit metabolism such as flesh darkening and softening (Pesis and Ben-Arie, 1984). In addition, Itamura et al. (1997) reported that 'Saijo' persimmon treated with $\mathrm{CO}_{2}$ to remove astringency showed an enhancement on ethylene production after treatment. Consequently, we assumed that possibly $18 \mathrm{~h}$ of exposition to $70 \mathrm{kPa} \mathrm{CO}_{2}$ may have stressed the tissue and stimulated ethylene synthesis leading to an increase in hydrolytic enzymes.

Upon removal from cold storage after 30 and 45 days, the yellow stage fruit had the higher flesh firmness in relation to other treatments, independently of carbon dioxide 
exposure time (Fig. 2B, C). The maximum storage life of red stage fruit was 30 days, from this time senescence symptoms were observed. In contrast, even after 45 days of cold storage plus one day at $22^{\circ} \mathrm{C}$, yellow stage persimmon submitted to 12 or $18 \mathrm{~h}$ to $\mathrm{CO}_{2}$ remained with higher flesh firmness. Conversely, at four days of shelf life the firmness of yellow stage fruit was comparable to orange stage fruit treated during $12 \mathrm{~h}$ with $\mathrm{CO}_{2}$ (Fig. 2C).

Immediately after the exposure to $\mathrm{CO}_{2}$ treatment the red stage fruit submitted to $\mathrm{CO}_{2}$ during $12 \mathrm{~h}$ showed highly astringent, while fruits at yellow and orange stage ranged from slight astringent to astringent (Fig. 3). Only after four days at $22^{\circ} \mathrm{C}$ the astringency was removed in all the fruits, independently of ripening stage or exposure time to $\mathrm{CO}_{2}$. Gazit and Adato (1972) reported two stages in the disappearance of astringency following $\mathrm{CO}_{2}$ gas treatment, an inductive one in which fruits are held in a certain period in a high $\mathrm{CO}_{2}$ atmosphere and a second stage in which the fruits actually lose their astringency which generally occurs after four days at ambient temperature. Whether this process is not concluded completely tannins can be resolubilized as reported in 'Triumph' (Ben-Arie and Sonego, 1993) and 'Rama Forte' persimmon (Edagi et al., 2006).

Fruits removed from $1{ }^{\circ} \mathrm{C}$ after one month of storage were prone to consume, except the orange stage fruits submitted to $70 \mathrm{kPa}$ of $\mathrm{CO}_{2}$ during $12 \mathrm{~h}$. In those fruit the astringency remained at a moderate index even after seven days of shelf life period (Fig. $3 \mathrm{~B}$ ). At the end of cold storage period (45 days) plus one day of shelf life fruit at yellow and orange stage were completely non-astringent. Taira et al. (1990) reported that the decrease in soluble tannins was faster, and acetaldehyde was produced more abundantly in immature fruit than in mature fruit of 'Hiratanenashi' during an ethanol treatment and suggested that the difference was due to the more active conversion of ethanol to acetaldehyde in immature fruit. According to Salvador et al. (2008), the lower reduction on soluble tannins in 'Rojo Brillante' persimmon is related to diffusion of $\mathrm{CO}_{2}$ through the cellular spaces which is more difficult when fruits are stored at long term; as a result there is a low rate of anaerobic respiration and consequently less accumulation of acetaldehyde in the flesh. This may explain the partial astringency at 15 and 30 days at $1^{\circ} \mathrm{C}$ even after the exposure to ambient temperature.

Traditionally 'Rama Forte' persimmon fruits are consumed soft in Brazil. This fact is because people believe that only at this stage the fruit can be consumed. In an attempt to change this situation, several trials have been carried out by our group to encourage the acceptance of firmer fruit consumption. As a direct and immediate consequence to this change on consuming pattern, the postharvest life of fruits can be considerably extended. Through astringency removal of fruits at yellow stage with $\mathrm{CO}_{2}$ and subsequent cold storage it is possible to ensure the enlargement of supply for at least one month and reduce the postharvest loss due to over maturity.

The exposure time of fruits to $\mathrm{CO}_{2}$ had no effect on lightness ( $\left.\mathrm{L}^{*}\right)$ of skin and pulp after the deastringency process (Fig. 4). It was observed that regardless of ripening stage of fruits and exposure time to $\mathrm{CO}_{2}$, there was a decreasing on $\mathrm{L}^{*}$ values of both, skin and pulp of fruits in all the storage periods. This reduction is related to browning of fruits as a whole during the shelf life period.

In relation to color parameter $\mathrm{a}^{*}$ it was possible to distinguish two distinct behaviors which were similar in all storage periods (Fig. 4). After 15 days at $1^{\circ} \mathrm{C}$, orange and red fruits showed increasing $\mathrm{a}^{*}$ values at the open chamber. This pattern represents a reddish skin. However, the exposure of fruits to ambient temperature during shelf life promotes significant decrease on $\mathrm{a}^{*}$ values, representing, skin and pulp browning. On the other hand, yellow stage fruits remained constant (Fig. 4C) or showed a slight increase in $a^{*}$ values (Fig. $4 \mathrm{G}, \mathrm{K}$ ) after four and seven days at $22^{\circ} \mathrm{C}$, in this case, this increase is related to the normal process of fruit maturation.

In general, while orange stage fruits showed characteristic symptoms of senescence at the end of storage period, the yellow stage fruits treated for 12 or $18 \mathrm{~h}$ remained edible even after shelf life period.

Hence we conclude that $\mathrm{CO}_{2}$ exposure of yellow stage persimmon during $12 \mathrm{~h}$ and 
subsequent storage at $1{ }^{\circ} \mathrm{C}$ maintain adequate quality attributes of fruit for up to 45 days plus one day of shelf life. Astringency removal is more effective on fruits at early ripening stage, and this process is dependent on exposure time to $\mathrm{CO}_{2}$ as late as the ripening stage.

\section{ACKNOWLEDGEMENTS}

Paulo (FAPESP).

This work was supported by Fundação de Amparo à Pesquisa do Estado de São

\section{Literature Cited}

Antoniolli, L.R., Castro, P.R.C., Kluge, R.A. and Scarpare Filho, J.A. 2002. A remoção da adstringência de frutos de caquizeiro 'Giombo' sob diferentes temperaturas. Pesq. Agr. Bras. 37:687-691.

Beaudry, R.M. 1999. Effect of $\mathrm{O}_{2}$ and $\mathrm{CO}_{2}$ partial pressure on selected phenomena affecting fruit and vegetable quality. Postharvest Biol. Technol. 15:293-303.

Ben-Arie, R. and Guelfat-Reich, S. 1976. Softening effects of $\mathrm{CO}_{2}$ treatment for removal of astringency from stored persimmon fruits. J. Amer. Soc. Hort. Sci. 101:179-181.

Ben-Arie, R. and Sonego, L. 1993. Temperature affects astringency removal and recurrence in persimmon. J. Food Sci. 58:1397-1400.

Edagi, F.K., Terra, F.A.M., Miguel, P. and Kluge, R.A., 2006. Recorrência de adstringência em frutos de caqui cv. Rama-Forte destanizados com dióxido de carbono. Anais do Simpósio Internacional de Iniciação Científica da Universidade de São Paulo.

Gazit, S. and Adato, I. 1972. Effect of carbon dioxide atmosphere on the course of astringency disappearance of persimmon (Diospyrus kaki Linn) fruits. J. Food Sci. 37:815-817.

Gazit, S. and Levy, Y. 1963. Astringency and its removal in persimmon. Israel J. Agr. Res. 13:125-132.

Itamura, H., Ohno, Y. and Yamamura, H. 1997. Characteristics of fruit softening in Japanese persimmon 'Saijo'. Acta Hort. 436:179-188.

Matsuo, T. and Itoo, S. 1977. On mechanisms of removing astringency in persimmon fruits by carbon dioxide treatment I. Some properties of the two processes in the deastringency. Plant and Cell Phys. 18:17-25.

Pesis, E. and Ben-Arie, R. 1984. Involvement of acetaldehyde and ethanol accumulation during induced deastringency of persimmon fruits. J. Food Sci. 49:896-899.

Salvador, A., Arnal, L., Besada, C., Larrea, V., Hernando, I. and Pérez-Munuera, I. 2008. Reduced effectiveness of the treatment for removing astringency in persimmon fruit when stored at $15^{\circ} \mathrm{C}$ : Physiological and microstructural study. Postharvest Biol. Technol. 49:340-347.

Taira, S., Itamura, H., Abe, K., Ooi, K. and Watanabe, S. 1990. Effect of harvest maturity on removal of astringency in Japanese persimmon (Diospyros kaki Thunb.), 'Hiratanenashi' fruits. J. Jpn. Soc. Hort. Sci. 58:813-818.

Vidrih, R., Simcic, M., Hribar, J. and Plestenjak, A. 1994. Astringency removal by high $\mathrm{CO}_{2}$ treatment in persimmon fruit (Diospyros kaki). Acta Hort. 368:652-656.

Vitti, D.C.C., Maia, F.A., Terra, F.A.M., Edagi, F.K. and Kluge, R.A. 2007. Efeito da época de colheita e de agentes destanizadores sobre a quantidade de acetaldeído e etanol em caquis 'Rama-Forte'. II Workshop Internacional de Pós-Colheita de Frutas, Campinas, SP.

Yamada, M., Taira, S., Ohtsuki, M., Sato, A., Iwanami, H., Yakushiji, H., Wang, R., Yang, Y. and Li, G. 2002. Varietal differences in the ease of astringency removal by carbon dioxide gas and ethanol vapor treatments among Oriental astringent persimmons of Japanese and Chinese origin. Sci. Hort. 94:63-72. 


\section{Figures}
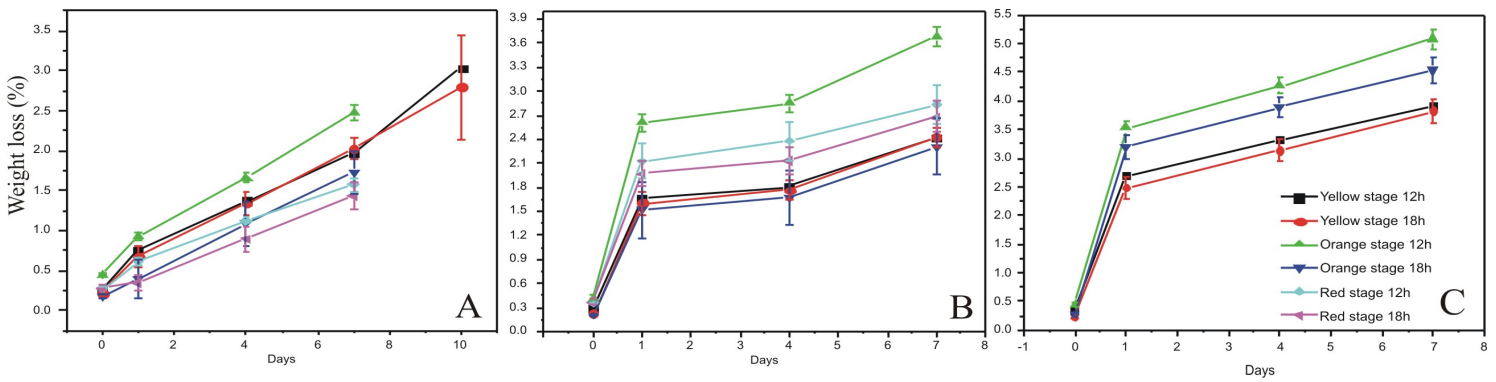

Fig. 1. Weight loss in 'Rama Forte' persimmon after 15 (A), 30 (B) and 45 (C) days at $1{ }^{\circ} \mathrm{C}$ with $90 \% \mathrm{RH}$ plus seven days at $22^{\circ} \mathrm{C}$.
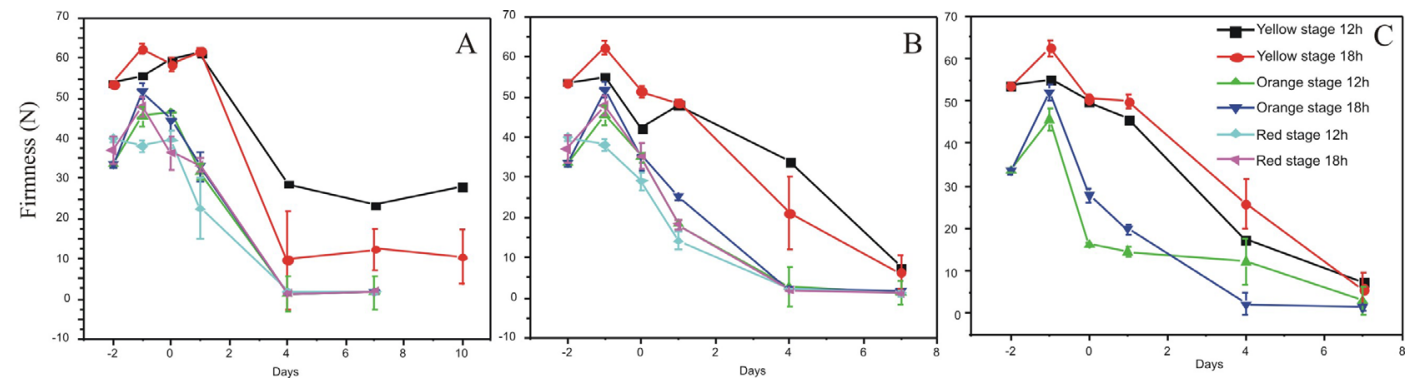

Fig. 2. Flesh firmness of 'Rama Forte' persimmon after 15 (A), 30 (B) and 45 (C) days at $1^{\circ} \mathrm{C}$ with $90 \% \mathrm{RH}$ plus seven days at $22^{\circ} \mathrm{C}(-2$ and -1 days represent before and after astringency removal, respectively).
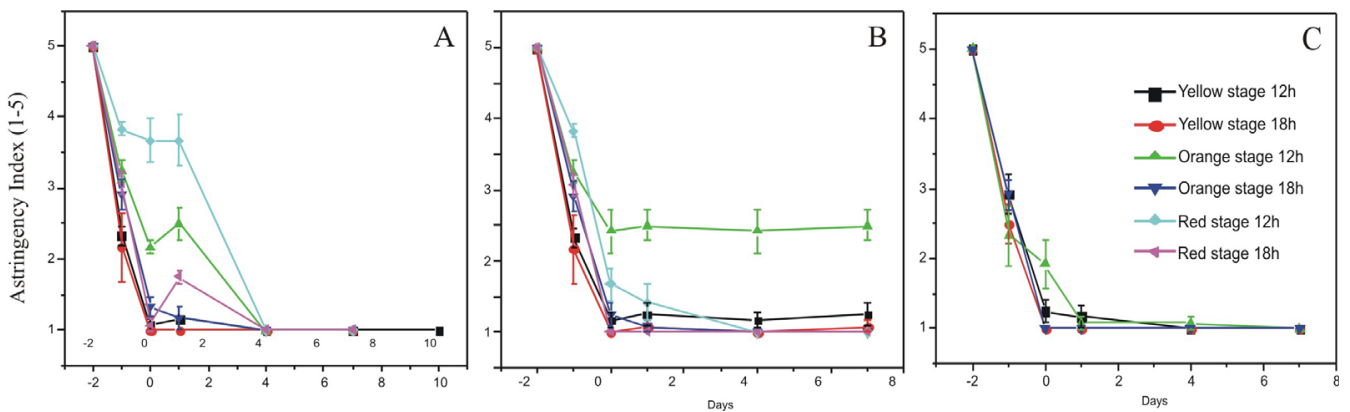

Fig. 3. Astringency Index of 'Rama Forte' persimmon after 15 (A), 30 (B) and 45 (C) days at $1{ }^{\circ} \mathrm{C}$ with $90 \% \mathrm{RH}$ plus seven days at $22^{\circ} \mathrm{C}(-2$ and -1 days represent before and after astringency removal, respectively). 

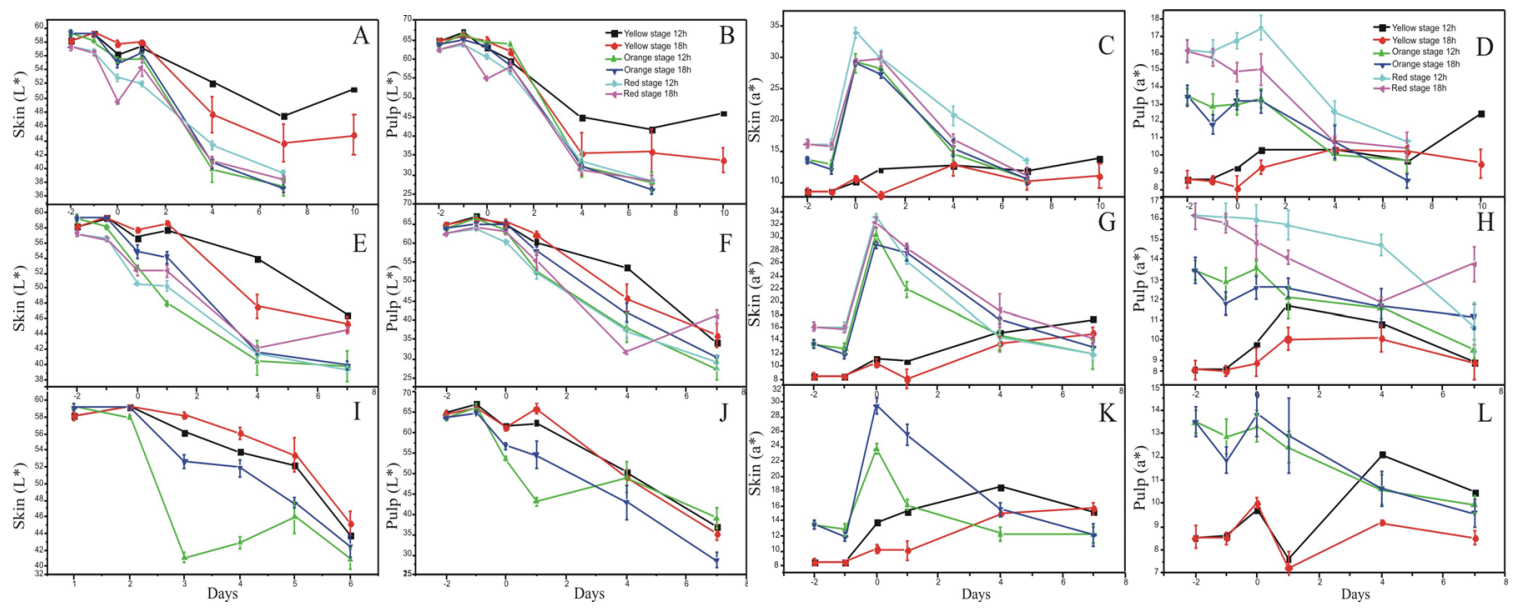

Fig. 4. Lightness L* of skin at 15 (A), 30 (E) and 45 (I) days; L* of pulp at 15 (B), 30 (F) and $45(\mathrm{~J})$ days; $\mathrm{a}^{*}$ of skin at $15(\mathrm{C}), 30(\mathrm{G})$ and $45(\mathrm{~K})$ days and $\mathrm{a}^{*}$ of pulp at 15 (D), $30(\mathrm{H})$ and $45(\mathrm{~L})$ days at $1{ }^{\circ} \mathrm{C}$ with $90 \% \mathrm{RH}$ plus seven days at $22^{\circ} \mathrm{C}$. $(-2$ and -1 days mean before and after astringency removal and 0 represent at the open chamber, respectively). 